\title{
Breath-holding Spells: Etiological Factors, Laboratory Findings, and Rates of Response to Iron Therapy
}

\author{
Katılma Nöbetleri: Etiyolojik Faktörler, Laboratuvar \\ Bulguları ve Demir Tedavisine Yanıt Oranları
}

\begin{abstract}
Aim: In this study, we aimed to investigate the etiological factors, electroencephalographic (EEG) findings, rates of response to iron therapy, and factors affecting response to iron therapy in children diagnosed with breath-holding spells (BHS)

Methods: The study included 136 children aged 1 to 48 months who received iron therapy after a BHS diagnosis at our pediatric neurology clinic between November 2015 and November 2019 Patient medical records (physical examination, laboratory and EEG findings, medical history, and effectiveness of iron therapy) were reviewed retrospectively.

Results: Of all patents, 81 (59.6\%) exhibited partial response (partial remission) to iron therapy (50\% decrease in BHS frequency), 52 (39\%) responded completely (complete remission), and 2 were unresponsive. Comparison of the patients with complete and partial remission revealed a higher rate of complete remission in girls. In addition, patients with complete remission had higher levels of hemoglobin, MCV, and ferritin than those with partial remission. Complete remission rates were also higher in patients with normal EEG findings.

Conclusion: BHS in childhood is a benign, recurring, and non-epileptic disorder and its differentiation from epilepsy is important. Children with BHS respond well to iron therapy, which can be recommended even if the serum iron and ferritin levels are normal.

Keywords: breath-holding spells; electroencephalography; iron supplementation
\end{abstract}

\section{Öz}

Amaç: Bu çalıșmada katıma nöbeti (KN) tanısı almıș çocuklarda etiyolojik faktörleri, elektroensefalografi (EEG) bulgularını, demir tedavisine yanıt oranlarını ve demir tedavisine yanıtı etkileyen faktörleri araștırmak amaçlanmıștır.

Yöntem: Çalıșmaya Kasım 2015-Kasım 2019 döneminde çocuk nöroloji kliniğimizde KN tanısıyla demir tedavisi gören 1 ila 48 ay yașındaki 136 çocuk dahil edildi. Hasta kayıtları (fizik muayene, laboratuvar ve EEG bulguları; tıbbi öykü ve demir tedavisinin etkililiği) retrospektif olarak değerlendirildi. Bulgular: Hastaların 81'i (\%59,6) demir tedavisine kısmi yanıt (kısmi remisyon-KN sıklığında \%50 azalma), 52'si (\%39) tam yanıt (tam remisyon) verirken, 2 hasta yanıtsızdı. Demir tedavisine kısmi ve tam yanıt veren hastalar karșılaștırıldığında kızlarda tam yanıt verme oranı daha yüksekti. Ayrıca tam yanıt veren hastaların hemoglobin, MCV ve ferritin düzeyleri kısmi yanıt verenlere göre daha yüksekti. Aynı zamanda EEG bulguları normal olan hastalarda tam yanıt verme oranları daha yüksekti.

Sonuç: Çocukluk çağında KN iyi huylu, tekrarlayan ve epileptik olmayan bir bozukluktur ve epilepsiden ayırt edilmesi önemlidir. KN'li çocuklar demir tedavisine iyi yanıt verirler ve demir tedavisi serum demir ve ferritin düzeyleri normal olsa dahi önerilebilir

Anahtar Sözcükler: demir desteği; elektroensefalografi; katılma nöbetleri
Fatma Hanci', Sevim Turay ${ }^{2}$ Omer Faruk Tirink ${ }^{3}$, Nimet Kabakus $^{1}$

1 Division of Child Neurology, Department of Pediatrics, Faculty of Medicine, Abant Izzet Baysal University

2 Department of Pediatrics, Faculty of Medicine, Düzce University

${ }^{3}$ Department of Pediatrics, Faculty of Medicine, Abant İzet Baysal University

Received/Gelis : 19.09.2020 Accepted/Kabul: 06.12.2020

DOI: 10.21673/anadoluklin.797238

Corresponding author/Yazıșma yazar Fatma Hancl

Abant İzzet Baysal Üniversitesi Tıp Fakültesi, Pediatri Anabilim Dalı Çocuk Nörolojisi Bölümü, 14280 Bolu, Turkey

E-mail: fatmah.arslan@gmail.com

\section{ORCID}

Fatma Hanci: 0000-0002-1019-9207

Sevim Turay: 0000-0001-6002-052X Omer Faruk Tirink: 0000-0001-7364-7778 Nimet Kabakus: 0000-0002-5413-4157 


\section{INTRODUCTION}

Breath-holding spells (BHS) are a well-known entity occurring in 3-5\% of toddlers, mainly in children aged 6-18 months (1-3). Attacks are self-limiting and generally (90\%) resolve by the time patients reach school age (4-5 years) (2). However, very rarely $(4-5 \%)$, spells may persist for up to 7-8 years (4). BHS may be cyanotic (blue), pallid (pale), or mixed, depending on the color change during the occurrence (1-3). Pallid episodes are less common than cyanotic spells. Breathholding episodes involve infants crying for up to a minute, and then not inhaling until a point when they lose consciousness. A seizure may rarely be witnessed immediately after the loss of consciousness. The infant usually regains consciousness shortly afterward and resumes normal breathing (1). Although these spells are benign in nature, they may nevertheless cause fear and distress among parents.

Mechanisms believed to be involved in this phenomenon include genetic predisposition, dysregulation of the autonomic nervous system, and delayed brain-stem myelination (5-7). Anemia and iron deficiency have previously been linked to BHS, although the mechanism involved is still unclear $(1,2,8)$. Also, BHS may occasionally be an initial symptom of long QT syndromes or paroxysmal cardiac rhythm abnormalities (6). Electrocardiography (ECG) in terms of prolonged QT syndrome is therefore highly recommended. Comorbid myoclonic jerks and generalized seizures following crying attacks may be observed in severe pallid spells and, to a lesser extent, cyanotic spells (2). Studies on the findings of BHS electroencephalography (EEG) are currently insufficient.

In this study, we aimed to investigate (i) the etiological factors involved in BHS, (ii) associated EEG findings, and (iii) rates of response to iron therapy and factors affecting the treatment response.

\section{MATERIALS AND METHODS}

The retrospective study included 136 children diagnosed with BHS between November 2015 and November 2019 at our pediatric neurology clinic. The age of onset ranged from one month to four years. We excluded children with (i) primary neurological disease, a history of epilepsy or febrile convulsions, or ab- normal neurological examination, (ii) mimics such as syncope, atonic fits, (iii) a history of chronic medical illness or systemic inflammation (since these lead to decreased erythropoietin production, impair blood cell proliferation, and alter iron absorption), (iv) congenital heart disease, (v) global developmental delay, and (vi) severe anemia (hemoglobin $[\mathrm{Hb}$ ] levels of $<7 \mathrm{~g} / \mathrm{dL}$ ).

Developmental history and BHS characteristics (including age of onset, frequency of spells, and family history of BHS, epilepsy or febrile convulsions) were recorded. The spell frequencies before and after threemonth treatment were recorded based on the statements provided by parents or legal guardians.

Spells were defined as described elsewhere based on the following clinical sequence: initial provocation prior to crying decreasing to silence (as the infant's breathing ceases in expiration following a deep inspiration during crying) and a simultaneous color change (cyanosis) and loss of consciousness, either with/without body tone changes or body jerks (2). In the present study, spells were classified on the basis of frequency, less than one a week being defined as mild, 1 to 3 a week as moderate, and four or more a week as high. The patients were divided into two groups according to their Hb levels: $>10.5 \mathrm{~g} / \mathrm{dl}$ (non-anemic) and $<10.5$ $\mathrm{g} / \mathrm{dl}$ (anemic). When they were re-evaluated after three-month iron therapy they were divided into three groups according to their response to the treatment: (1) no response, (2) partial remission $(>50 \%$ decrease in spell frequency), and (iii) complete remission (no spells).

All patients underwent medical examinations, and neurological histories were obtained together with ECG, echocardiography (ECO), and EEG. Complete blood counts $(\mathrm{CBC})$ and serum iron and ferritin values were determined from the basal laboratory tests at the time of initial presentation.

Iron deficiency refers to a serum ferritin value lower than $12 \mathrm{ng} / \mathrm{ml}$. Iron deficiency anemia (IDA) is characterized by iron deficiency and hemoglobin levels of $<10.5 \mathrm{~g} / \mathrm{dl}$ (9). All patients with BHS in the present study received iron therapy (ferrous sulfate at 4 $\mathrm{mg} / \mathrm{kg}$ per day) for three months. Monthly follow-ups were performed by the treating physicians.

The ECG and ECO assessments were made by the cardiology department in order to exclude cardiac 
Table 1. Sociodemographic and clinical characteristics of the patients

\begin{tabular}{|c|c|}
\hline Age at diagnosis (month), mean \pm SD & $22.5 \pm 10.2$ \\
\hline \multicolumn{2}{|l|}{ Sex, n (\%) } \\
\hline Female & $72(52.9)$ \\
\hline Male & $64(47.1)$ \\
\hline BHS with anemia, n (\%) & $70(51)$ \\
\hline Age of BHS onset, mean \pm SD & $13.1 \pm 8.0$ \\
\hline \multicolumn{2}{|l|}{ Family history of epilepsy, n (\%) } \\
\hline Yes & $26(19.1)$ \\
\hline No & $110(80.9)$ \\
\hline \multicolumn{2}{|l|}{ Family history of BHS, n (\%) } \\
\hline Yes & $21(15.4)$ \\
\hline No & $115(84.6)$ \\
\hline $\mathrm{Hb}(\mathrm{g} / \mathrm{dl})$, mean $\pm \mathrm{SD}$ & $11.3 \pm 0.9$ \\
\hline $\mathrm{MCV}$, mean $\pm \mathrm{SD}$ & $74.2 \pm 5.6$ \\
\hline Iron (ug/dl), mean $\pm \mathrm{SD}$ & $39.6 \pm 23.2$ \\
\hline Ferritin (ng/ml), mean \pm SD & $16.5 \pm 13.2$ \\
\hline \multicolumn{2}{|l|}{ EEG, n (\%) } \\
\hline Normal & $107(78.7)$ \\
\hline Abnormal & $27(19.9)$ \\
\hline Epileptiform & $2(1.5)$ \\
\hline \multicolumn{2}{|l|}{ BHS frequency, n (\%) } \\
\hline Severe & $30(22.1)$ \\
\hline Moderate & $48(35.3)$ \\
\hline Mild & $58(42.7)$ \\
\hline \multicolumn{2}{|l|}{ BHS frequency after prophylaxis, $n(\%)$} \\
\hline Partial response & $81(60.4)$ \\
\hline Complete response & $53(39.6)$ \\
\hline
\end{tabular}

BHS: breath-holding spells; EEG: electroencephalogram; $\mathrm{Hb}$ : hemoglobin; MCV: mean corpuscular volume; SD: standard deviation

pathologies. QT intervals were calculated in terms of long QT syndrome by using the Bazett formula.

All EEGs were assessed in a blinded manner by two pediatric neurologists experienced in the field of pediatric epilepsy. Scalp EEGs were recorded for all patients according to the international 10-20 system with a 19-electrode montage (Fp1, Fp2, F3, F4, C3, C4, P3, P4, O1, O2, F7, F8, T3, T4, T5, T6, Fz, Cz, and Pz). EEG channels were sampled at $500 \mathrm{~Hz}$ using Neurofax (Nihon Kohden Co., Tokyo, Japan). Findings were analyzed under three headings: (1) normal, (2) background rhythm abnormalities (slow waves), and (3) epileptic anomalies.

\section{Statistical analysis}

Statistical analysis was performed using the SSPS (25.0) software (SPSS Inc., Chicago, Illinois, USA). Continuous data were expressed as mean \pm standard deviation (minimum-maximum) and categorical variables as frequencies and percentages. The statistical tests employed depended on data distribution, normal distribution being assessed by the Kolmogorov-Smirnov test. Non-normally distributed data were analyzed using the Mann-Whitney U test, while categorical data were subjected to Pearson's chi-square test and Fisher's exact test. The findings were analyzed with a $95 \%$ confidence interval and a significance level of $<0.05$.

\section{Study ethics}

The study protocol was approved by the local ethics committee (2018/191).

\section{RESULTS}

The mean patient age was $22.5 \pm 10.2$ months. Of all patients, 72 (52.9\%) were girls, and 64 (47.1\%) were boys. The mean age of BHS onset was $13.1 \pm 8.0$ months. A family history of epilepsy and BHS was present in 26 (19.1\%) and 21 (15.4\%) patients, respectively. The mean $\mathrm{Hb}, \mathrm{MCV}$, and ferritin values were $11.3 \pm 0.9 \mathrm{~g} / \mathrm{dl}$, $74.2 \pm 5.6$, and $16.5 \pm 13.2 \mathrm{mcg} / \mathrm{L}$, respectively. ECO was abnormal (mild ME and TE) in four (2.9\%) patients, while QTc was normal in all patients. Twenty-seven (19.9\%) patients had background rhythm abnormality (slow waves) on EEG, and 2 (1.5\%) had epileptiform EEG. Eighty-one (59.6\%) exhibited a partial response (partial remission) to iron therapy (50\% decrease in spell frequency), and 52 (39\%) responded completely (complete remission). Two patients were unresponsive. Spell frequencies were severe in $30(22.1 \%)$ patients, moderate in 48 (35.3\%), and mild in 58 (42.7\%). The incidence of anemia in patients with BHS was $51 \%$ (Table 1).

Comparison of patients with complete and partial remission revealed a higher rate of complete remission in girls. The mean $\mathrm{Hb}$ levels were also higher in patients with complete remission following iron therapy than in those exhibiting partial remission, while there was no significant difference between the two groups in terms of MCV and ferritin levels. The rate of com- 
Table 2. Univariate comparisons of patient characteristics in the partial and complete remission groups

\begin{tabular}{|c|c|c|c|}
\hline & Partial remission $(n=81)$ & Complete remission $(n=53)$ & $p$ \\
\hline Age at diagnosis, mean \pm SD & $23.1 \pm 11.7$ & $22.03 \pm 7.9$ & $1.00^{\mathrm{a}}$ \\
\hline Sex, n (\%) & & & $0.014^{\mathrm{b}}$ \\
\hline Female & $36(44.4)$ & $35(66)$ & \\
\hline Male & $45(55.6)$ & $18(34)$ & \\
\hline Family history of epilepsy, n (\%) & & & $0.89^{\mathrm{b}}$ \\
\hline Yes & $16(19.8)$ & $10(18.9)$ & \\
\hline Mo & $65(80.2)$ & $43(81.1)$ & \\
\hline Family history of BHS, n (\%) & & & $0.10^{\mathrm{b}}$ \\
\hline Yes & $16(19.8)$ & $5(9.4)$ & \\
\hline No & $65(80.2)$ & $48(90.6)$ & \\
\hline Frequency of BHS, n (\%) & & & $0.001^{b}$ \\
\hline Severe & $6(7.4)$ & $23(43.4)$ & \\
\hline Moderate & $32(39.5)$ & $15(28.3)$ & \\
\hline Mild & $43(53)$ & $15(28.3)$ & \\
\hline $\mathrm{Hb}$, mean $\pm \mathrm{SD}$ & $11.15 \pm 1$ & $11.5 \pm 0.74$ & $0.035^{a}$ \\
\hline $\mathrm{MCV}$, mean $\pm \mathrm{SD}$ & $72.9 \pm 5.5$ & $74.8 \pm 5.6$ & $0.06^{\mathrm{a}}$ \\
\hline Iron, mean \pm SD & $37 \pm 20$ & $41 \pm 21$ & $0.57^{\mathrm{a}}$ \\
\hline Ferritin, mean $\pm S D$ & $13.4 \pm 9.3$ & $17.9 \pm 13.7$ & $0.051^{\mathrm{a}}$ \\
\hline EEG, n (\%) & & & $0.021^{b}$ \\
\hline Normal & $70(86.3)$ & $37(69.8)$ & \\
\hline Abnormal & $11(13.6)$ & $16(30.2)$ & \\
\hline \multicolumn{4}{|c|}{ BHS: breath-holding spells; EEG: electroencephalogram; Hb: hemoglobin; MCV: mean corpuscular volume } \\
\hline \multicolumn{4}{|c|}{ Bold p-values indicate statistical significance at $\alpha=0.05$} \\
\hline \multicolumn{4}{|c|}{ a Mann-Whitney U test } \\
\hline \multicolumn{4}{|l|}{${ }^{\mathrm{b}}$ Pearson's chi-square test } \\
\hline${ }^{\mathrm{c}}$ Fisher's exact test & & & \\
\hline
\end{tabular}

plete response to iron therapy was higher in patients with normal EEGs. There was no statistically significant difference in response rates between patients with a family history of epilepsy and BHS (Table 2).

The spell frequencies and treatment responses of patients with and without IDA are shown in Table 3. The incidence of mild frequency spells was higher in the non-anemic group. Complete response to iron therapy (complete remission) was also more common in the non-anemic group.

One of the patients with epileptiform EEG and not responding to iron therapy was a 12 -month-old girl, who had been born by cesarean section at 30 weeks of gestation with a birth weight of $830 \mathrm{~g}$ and who had spent two months in the neonatal intensive care unit. The first BHS occurred at four months of age, and spells occurred approximately 3 or 4 times weekly.
There was no family history of BHS or epilepsy. Neurological examination and neurodevelopment were normal, but focal epileptiform EEG was observed. The patient failed to respond to iron therapy. MRI revealed polymicrogyria and cortical dysplasia. Levetiracetam (30 $\mathrm{mg} / \mathrm{kg}$ per day) was added to the treatment. The patient is currently under medical management.

The other patient who did not respond to iron therapy was a 13-month-old boy. His prenatal, natal and postnatal histories and EEG and MRI findings were normal. There was no family history of BHS or epilepsy. The first BHS occurred at six months of age, and he had daily attacks. Due to the lack of response to iron therapy, piracetam was added to the treatment, after which the attacks decreased significantly. 
Table 3. The effect of iron deficiency anemia (Hb level) on spell frequency and response to iron therapy

\begin{tabular}{|c|c|c|c|}
\hline & $\mathrm{Hb}<10.5 \mathrm{~g} / \mathrm{dl}$ & $\mathrm{Hb}>10.5 \mathrm{~g} / \mathrm{dl}$ & $p$ \\
\hline$(\mathrm{n}=25)$ & $(n=110)$ & & \\
\hline Sex, n (\%) & & & $0.20^{\mathrm{a}}$ \\
\hline Female & $12(48)$ & $51(46.4)$ & \\
\hline Male & $13(52)$ & $59(53.6)$ & \\
\hline BHS frequency, $\mathrm{n}(\%)$ & & & $0.022^{\mathrm{a}}$ \\
\hline Severe & $10(40)$ & $20(18.2)$ & \\
\hline Moderate & $10(40)$ & $38(34.5)$ & \\
\hline Mild & $5(20)$ & $52(47.3)$ & \\
\hline Response to iron therapy, $\mathrm{n}(\%)$ & & & $0.006^{\mathrm{a}}$ \\
\hline Complete remission & $9(36)$ & $71(65.7)$ & \\
\hline Partial remission & $16(64)$ & $37(34.3)$ & \\
\hline
\end{tabular}

Bold p-values indicate statistical significance at $\alpha=0.05$

${ }^{a}$ Pearson's chi-square test

\section{DISCUSSION AND CONCLUSION}

We observed that our sample included more girls than boys, and rates of complete remission with iron therapy were also higher in girls. Previous studies have reported a male predominance (8) or no significant sex difference $(2,3,10,11)$. The female predominance in the present study may be due to the sample selection. The mean age of onset was 13.1 months, and the earliest age of onset was one month. The earliest age of onset reported in previous studies is three days, in a case with a family (father, sister, and paternal grandfather) history of the condition (12). The reported mean age of onset is generally 6-12 months $(2,8,9)$.

The reported incidence of a family history of epilepsy has ranged from 7.7 to $29 \%(10,13,14)$. In consistence with the previous literature, the same figure was determined to be $19.1 \%$ in our study.

Previous studies have shown that genetic predisposition plays an important role in the BHS etiology $(2,15,16)$. In their family pedigree study, DiMario et al. (17) proposed an autosomal dominant trait with reduced penetrance as the most likely inheritance pattern in cases of severe BHS. The prevalence of family history of BHS in the present study was $15.4 \%$, lower than in the previous literature. Data on the genetic predisposition or family history of BHS may vary between countries. Studies from Turkey have reported similar figures $(10,11)$.
One study of 115 patients with long QT syndrome reported BHS as a presentation symptom in five (18). In our study, we identified no patients with long QT syndrome. It may rarely be seen in patients with BHS and we therefore think that ECG and QTc should be calculated.

In a study of 129 patients ( 77 boys, 52 girls), all but one patient had normal EEGs. One tracing taken during a BHS showed a slow wave but no seizure activity (19). Sleep EEGs were recorded for all patients in another study, 98.2\% ( $\mathrm{n}=306)$ of which were normal, while slow background rhythm was determined in $1.2 \%(n=4)$. In addition, in another study, only 18 out of 165 patients had encephalographic abnormalities, and only one patient was diagnosed with epilepsy (14). In the present study, EEG was normal in 107 (78.7\%) patients, while slow waves of background rhythm were present in 27 (19.9\%), and two patients had epileptiform EEGs. Only one of these patients failed to respond to iron therapy. The patient had focal epileptiform EEG, and cortical dysplasia and polymicrogyria were detected on brain MRI. In a similar case from the literature, a 14-month-old, developmentally normal girl presented with daily events since six months of age. Episodes were characterized by crying (provoked by falls or anger). This was then followed by cessation of crying, perioral cyanosis, and tonic stiffening of the limbs and jerking. BHS with reflex-anoxic seizures were diagnosed, and the patient was started on 
iron therapy but failed to benefit. These episodes later began occurring without crying spells. Seizures were suspected. Minimal response was achieved to phenobarbital and levetiracetam therapy, but a significant decrease in episodes, to one a month, was observed when oxcarbazepine was added to the treatment. The patient has currently been seizure-free for two months. MRI revealed focal cortical dysplasia type I. Video-EEG revealed generalized seizures (both spontaneous and induced by breath-holding) with unclear lateralization. Targeted epilepsy gene panel revealed a de novo previously described pathogenic variant in the SCN8A gene linked to milder phenotypes (20). Our patient had no spontaneous episodes. However, since these are possible at follow-up, close monitoring from that perspective is required. Genetic analysis was not possible for financial and technical reasons.

The prevalence of anemia in BHS in the present study was $51 \%$ (32\% grade 1 anemia, low ferritin, normal $\mathrm{Hb}$ ), compared to the widely varying rates of 7.5 to $69 \%$ in the literature $(21,22)$.

One study reported rates of higher complete and partial remission with iron therapy in patients with low mean $\mathrm{Hb}$ levels (23). In another study, all patients, with or without IDA, received iron therapy $(4 \mathrm{mg} / \mathrm{kg} /$ day) and the treatment responses in anemic and nonanemic patients revealed a decreased spell burden and attack duration in both groups, although neither finding was statistically significant (10). In another study, frequency of spells at diagnosis and intolerance to oral iron were significantly associated with poor response to iron supplementation. No relationship was observed between response and other factors including age of onset, age at presentation, severity of spells, anemia, and serum iron parameters. Of 27 children without iron deficiency (serum ferritin levels $\geq 30 \mu \mathrm{g} / \mathrm{L}$ ), $77.7 \%$ responded completely to iron therapy, consistent with the iron-deficient group (8). In the present study, the complete remission rate following iron therapy was significantly higher in patients without IDA than in anemic patients. In addition, when given iron supplementation, patients with BHS without IDA could show similar or even better response, as reported in previous studies $(8,10)$. In contrast to the study of Jain et al. (20), the present study found a significantly higher rate of complete remission with iron therapy in patients with a greater BHS frequency. The complete remission rate was $39.5 \%$ (53 patients). Rates of complete remission were higher in girls, in patients with a severe spell frequency, and in patients with normal EEG and high levels of mean $\mathrm{Hb}$. The number of studies evaluating factors affecting complete remission is limited.

Various explanations have been offered for the EEG background rhythm abnormalities seen in BHS. Anemia is considered the principal cause of decreased cerebral blood flow. Iron is also known to be involved in the catecholamine metabolism, and changes occur in neurotransmission in the central nervous system in the event of iron deficiency (24). Clinical and laboratory findings have been reported to be potentially associated with cerebral erythropoietin, nitric oxide, and interleukin-1 levels $(24,25)$. Additionally, animal experiments have shown changes in the cerebral dopamine metabolism in iron deficiency $(26,27)$. In a study, the EEGs of children with iron deficiency exhibited slower activity than those of a control group, which might be associated with central nervous system dysfunction (28). We think that the EEG background rhythm abnormality in the present study may be due to neurodysfunction resulting from iron deficiency.

Our study has several limitations, the main of which are the retrospective design and the absence, for ethical reasons, of a control group. Another limitation is the lack of data on the third-month hemoglobin and ferritin levels and follow-up EEGs. However, a particular strength of the present study is that it is one of the few studies to evaluate complete and partial remission with iron therapy in a sufficiently large number of patients.

BHS are a non-epileptic paroxysmal disorder that may be confused with epilepsy, one that is frequently seen in the infantile period and may require EEG, particularly in the case of prolonged and frequent attacks. In addition, ECG as an easy and inexpensive technique may be recommended for differential diagnosis in cases with cardiac arrhythmias. We recommend that iron therapy should be tried in all patients diagnosed with BHS (even without IDA), and that the treatment should be switched to alternative methods when no response has been achieved.

In conclusion, compared to patients with IDA, a similar or even better response can be achieved in pa- 
tients with BHS without IDA. It should also be emphasized that the rate of response to iron therapy may be higher in female patients and in patients with a high frequency of attacks. Further prospective studies at the cellular level are needed to elucidate why patients with BHS respond well to iron therapy even in the absence of IDA.

\section{Conflict-of-Interest and Financial Disclosure}

The authors declare that they have no conflict of interest to disclose. The authors also declare that they did not receive any financial support for the study.

\section{REFERENCES}

1. Evans OB. Breath-holding spells. Pediatr Ann. 1997;26(7):410-4.

2. DiMario FJ. Prospective study of children with cyanotic and pallid breath-holding spells. Pediatrics. 2001;107(2):265-9.

3. Carman KB, Ekici A, Yimenicioglu S, Arslantas D, Yakut A. Breath holding spells: point prevalence and associated factors among Turkish children. Pediatr Int. 2013;55(3):328-31.

4. Goraya JS, Virdi VS. Persistence of breath-holding spells into late childhood. J Child Neurol. 2001;16(9):697-8.

5. Tomoum H, Habeeb N, Elagouza I, Mobarez H. Paediatric breath-holding spells are associated with autonomic dysfunction and iron deficiency may play a role. Acta Paediatr. 2018;107(4):653-57.

6. DiMario FJ, Burleson JA. Autonomic nervous system function in severe breath-holding spells. Pediatr Neurol. 1993;9(4):268-74.

7. Vurucu S, Karaoglu A, Paksu SM, Oz O, Yaman H, Gulgun $\mathrm{M}$, et al. Breath-holding spells may be associated with maturational delay in myelination of brain stem. J Clin Neurophysiol. 2014;31(1):99-101.

8. Jain R, Omanakuttan D, Singh A, Jajoo M. Effect of iron supplementation in children with breath holding spells. J Paediatr Child Health. 2017;53(8):749-53.

9. Worwood M. Indicators of the iron status of populations: ferritin. In: Assessing the Iron Status of Populations: Report of a Joint World Health Organization/Centers for Disease Control and Prevention Technical Consultation on the Assessment of Iron Status at the Population Level, 2. ed. Geneva: World Health Organization; 2007:35-74.

10. Gürbüz G, Perk P, Çokyaman T, Gürbüz ÖB. Iron supplementation should be given in breath-holding spells regardless of anemia. Turk J Med Sci. 2019;49(1):230-7.

11. Dai AI, Demiryürek AT. Effectiveness oral theophylline, piracetam, and iron treatments in children with simple breath-holding spells. J Child Neurol. 2020;35(1):25-30.

12. Breukels MA, Plötz FB, van Nieuwenhuizen O, van Diemen-Steenvoorde JA. Breath holding spells in a 3-dayold neonate: an unusual early presentation in a family with a history of breath holding spells. Neuropediatrics. 2002;33(1):41-2.

13. Hamed SA, Gad EF, Sherif TK. Iron deficiency and cyanotic breath-holding spells: the effectiveness of iron therapy. Pediatr Hematol Oncol. 2018;35(3):186-95.

14. Yilmaz U, Doksoz O, Celik T, Akinci G, Mese T, Yilmaz TS. The value of neurologic and cardiologic assessment in breath holding spells. Pak J Med Sci. 2014;30(1):59-64.

15. Silbert PL, Gubbay SS. Familial cyanotic breath-holding spells. J Paediatr Child Health. 1992;28(3):254-6.

16. Olsen AL, Mathiasen R, Rasmussen NH, Knudsen FU. Long-term prognosis for children with breath-holding spells. Dan Med Bull. 2010;57(11):A4217.

17. DiMario FJ, Sarfarazi M. Family pedigree analysis of children with severe breath-holding spells. J Pediatr. 1997;130(4):647-51.

18. Robinson JA, Bos JM, Etheridge SP, Ackerman MJ. Breath holding spells in children with long QT syndrome. Congenit Heart Dis. 2015;10(4):354-61.

19. Low NL, Gibbs EL, Gibbs FA. Electroencephalographic findings in breath holding spells. Pediatrics. 1955;15(5):595-9.

20. Jain P, Gulati P, Morrison-Levy N, Yau I, Alsowat D, Otsubo $\mathrm{H}$, et al. "Breath holding spells" in a child with SCN8A-related epilepsy: expanding the clinical spectrum. Seizure. 2019;65:129-30.

21. Schmidt SH, Tedgård U, Pronk CJ. Breath-holding spells occur disproportionately more often in children with transient erythroblastopenia. Acta Paediatr. 2016;105(9):1088-93.

22. Sadek AA, Mohamed MM, Sharaf ZSA, Magdy RM, Allam AA. Clinico-laboratory profile of breath-holding spells in children in Sohag University Hospital, Upper Egypt. Electron Physician. 2016;8(4):2227-31.

23. Daoud AS, Batieha A, al-Sheyyab M, Abuekteish F, Hijazi S. Effectiveness of iron therapy on breath-holding spells. J Pediatr. 1997;130(4):547-50.

24. Bakoyiannis I, Gkioka E, Daskalopoulou A, Korou LM, Perrea D, Pergialiotis V. An explanation of the pathophysiology of adverse neurodevelopmental outcomes in iron deficiency. Rev Neurosci. 2015;26(4):479-88.

25. Masuda S, Okano M, Yamagishi K, Nagao M, Ueda M, 
Sasaki R. A novel site of erythropoietin production. Oxygen-dependent production in cultured rat astrocytes. J Biol Chem. 1994;269(30):19488-93.

26. Beard JL. Iron deficiency and neural development: an update. Arch Latinoam Nutr. 1999;49(3):34-9.

27. Youdim MB, Yehuda S. The neurochemical basis of cognitive deficits induced by brain iron deficiency: involvement of dopamine-opiate system. Cell Mol Biol. 2000;46(3):491-500.
28. Lozoff B, Jimenez E, Hagen J, Mollen E, Wolf AW. Poorer behavioral and developmental outcome more than 10 years after treatment for iron deficiency in infancy. Pediatrics. 2000;105(4):E51. 